\title{
Türkiye’de Bulunan Eğitim Çağındaki Suriyeli Mültecilerin Eğitimi Sorunu
}

\section{(Van İli Örneği)*}

\section{Hasan Basri MEMDUHOĞLU ${ }^{* *}$ ve Emrah KULTAS ${ }^{* * *}$}

Öz: Bu çalışmanın amacı, 2017 yılında Türkiye'ye göç edip Van ilinde yaşamlarını sürdüren eğitim çağındaki Suriyeli mültecilerin yaşadıkları eğitim sorunlarını açığa çıkararak çözüm önerileri geliştirmektir. Nitel yöntemle yapılan bu çalışma, bir durum (vaka) çalışmasıdır. Araştırmanın çalışma grubunu, 2017 yılında Türkiye'ye göç etmiş ve Van ilinde yaşamlarını sürdüren eğitim çağındaki Suriyeli 13 (7 okula devam eden, 6 okula devam etmeyen) çocuk, 6 Suriyeli aile reisi, Van ilinde Suriyeli öğrencilerin 2016-2017 eğitim-öğretim yılında öğrenim gördüğü okullardaki 8 öğretmen ve 5 okul müdürü, 2 il milli eğitim yöneticisi (bir il milli eğitim müdür yardımcısı, bir il milli eğitim şube müdürü), il milli eğitimde görev yapan 7 maarif müfettişi, 1 sosyal yardımlaşma vakfı yöneticisi ve Van ilinde aktif olarak hizmet veren 4 sivil toplum kuruluşu ( 2 sendika, 2 yardım derneği) yöneticisi olmak üzere 46 kişi oluşturmaktadır. Veriler, yarı yapılandırılmış form kullanılarak görüşme tekniği ile elde edilmiştir. Araştırmanın verileri, içerik analizi yöntemi ile çözümlenmiştir. Araştırmada, Suriyeli ailelerin genel olarak barınma, beslenme ve uyum sorunu yaşadıkları, bu sorunların çocuklarının eğitimini olumsuz etkilediği, Suriyeli çocukların bu ve benzeri nedenlerle eğitimlerine devam etmediği ve bu yönde çeşitli taleplerinin olduğu sonucuna ulaşılmıştır.

Anahtar Kelimeler: Göç, Suriye, Eğitim sorunları, Göç ve eğitim, Suriyeli mülteciler.

\section{The Education Problem of the Syrian Refugees Located in Turkey (Sample for Van City)}

Abstract: The aim of this study is to disclose the education problems of the Syrian refugees who are at educational age and lead a life in Van in 2017, and also try to find suitable solutions for this problem. This study is a descriptive survey model which is a case study. The study group is consisted of 46 people; 13 Syrian refugee children who have migrated to Turkey in

\footnotetext{
*Bu çalışma, ikinci yazarın ilk yazar danışmanlığında 2017 yılında yürüttüğü yüksek lisans tezinden üretilmiştir. **Prof. Dr., Siirt Üniversitesi, Eğitim Fakültesi Dekanlığı, Email: hasanmemduhoglu@gmail.com, Orcid No: 0000-0001-5592-3166

***Doktora Öğrencisi, Gazi Üniversitesi, Eğitim Bilimleri Enstitüsü, Email: kultasemrah@gmail.com, Orcid No: 0000-0002-4041-8642
} 
2017 and have lived in Van (7 of them attend to school while 6 of them do not), 6 Syrian householders, 8 teachers and 5 school managers from the schools in which Syrian students have education in Van in the 2016-2017 academic year, 2 provincial administrators of national education (one assistant of provincial administrator of national education, one departmental manager of provincial directorate for national education), 7 education inspectors who work in Van, 1 administrator of social assistance and solidarity foundation and 4 civil society organizations ( 2 unions and 2 charities) which serve actively. The data is obtained with the interview technique which has been made by structured form. The study data is analyzed with content analysis method. In the study, it has been come through that Syrian families have generally harboring, food and compliance problems, these problems have affected the education of children, Syrian children do not maintenance their education because of those and suchlike problems, and they have requests about this matter.

Keywords: Migration, Syria, Education problems, Migration and education, Syrian refugees.

\section{Giriş}

Suriye'de yaşanan iç çatışmalar ve karışıklıklardan dolayı Suriye'den Türkiye’ye ilk olarak 2011 yılında 252 kişi giriş yapmış ve bu tarihten itibaren Türkiye'ye sığınan Suriyeli sayısı giderek artış göstermiştir (Afet ve Acil Durum Yönetimi Başkanlığı [AFAD], 2016). Yaşanan bu çatışmalardan milyonlarca kişi etkilenmiştir. Bu süreçte binlerce insan yaralanmış, çok sayıda insan hayatını kaybetmiştir. 2015 yılına gelindiğinde ise Suriye nüfusunun yarısından fazlası yaşadıkları toprakları terk edip farklı ülkelere göç etmek zorunda kalmıştır. Göç eden Suriyelilerin önemli bir kısmı komşu ülkeler olan Türkiye, Lübnan, Irak ve Mısır gibi ülkelere sığınmıştır (The UN Refugee Agency [UNCHR], 2015). Bu göç sürecinde şüphesiz Türkiye, konumu itibariyle Suriyeliler için büyük bir öneme sahip olmuştur. 2011 yılında Suriye'de başlayan iç savaş ve çatışmaların etkisiyle ülkelerinden göç etmek zorunda kalan Suriyelilerin önemli bir kısmına Türkiye ev sahipliği yapmaktadır.

İlk göç hareketinden bu yana Türkiye'deki Suriyeli sığınmacıların sayısı gün geçtikçe katlanarak devam etmiştir. 2017 yılı itibariyle Türkiye'de kayıtlı Suriyeli sayısı üç milyonu geçmiştir. Göçün ilk yıllarında Türkiye'de Suriye'deki çatışma ortamının uzun sürmeyeceği, göç eden Suriyelilerin uzun yıllar kalmayacağı düşüncesi hâkim olduğundan Suriyeliler için 
kısa vadeli çözümler düşünülmekteydi. Bu noktada, temel ihtiyaçlarının karşılanması noktasında Suriyelilerin belli bir bölgede toplanmaları gerektiği düşüncesinin etkisiyle Suriye sınırına yakın il ve ilçelerde geçici barınma merkezleri oluşturulmuştur. $\mathrm{Bu}$ barınma merkezlerine Suriyeli mülteciler yerleştirilmeye çalışılmıştır. Hatta Türkiye'nin çeşitli illerinde bulunan Suriyeliler bile il göç idareleri tarafından bu kamplara yönlendirilmiştir. Ancak Suriye'deki savaş ve çatışma ortamının bitmemesi, Suriye'deki durumların gittikçe kötü bir hal alması, Suriyelilerin uzun yıllar Türkiye'de kalacakları düşüncesini ortaya çıkarmıştır. Geçici barınma merkezlerinin sayısı artırılmaya çalışılmış; ancak bu merkezlerin göç eden Suriyelilerin tümünü barındırmasının mümkün olmayacağı görülmüştür.

Türkiye'de hali hazırda 10 ilde 23 barınma merkezi bulunmaktadır. Bu barınma merkezlerinde Suriyeli mültecilerin barınma ve beslenme gibi temel ihtiyaçları karşılanmaktadır. Bunun yanı sıra, bu barınma merkezlerinin içinde veya dışında geçici eğitim merkezleri oluşturularak Suriyeli çocukların eğitim ihtiyaçları da giderilmeye çalışılmaktadır. Ancak Göç İdaresi Genel Müdürlüğü (GİGM) 2017 yılı verilerine göre Türkiye’de bulunan Suriyeli mültecilerin \% 8'i gibi çok az bir kısmı bu kamplarda yaşamlarını sürdürürken; \% 92'lik gibi ciddi bir kısmı ise Türkiye'nin tüm illerine dağılarak bulundukları il ve ilçelerde yaşamlarını sürdürmeye çalışmaktadırlar. Türkiye'nin dört bir tarafına yayılan Suriyeliler sosyal, ekonomik, psikolojik gibi pek çok sorun yaşamaktadırlar. Bu durum, Türkiye'nin bu yönde önemli politikalar geliştirmesini zorunlu kılmaktadır.

Göç İdaresi Genel Müdürlüğü verilerine göre 06.07.2017 tarihi itibarıyla kamp içinde ve kamp dışında olmak üzere Türkiye'de toplam 3.079.914 Suriye vatandaşı bulunmaktadır. Bunların 244 bini AFAD tarafından 10 ilde kurulan 23 barınma merkezinde, geriye kalan iki milyon 834 bini ise kamp dışında yaşamlarını sürdürmektedir (GİGM, 2017).

Geçici koruma kapsamındaki Suriyeli mülteci sayısı, her geçen yıl artmaktadır. 2012 yılında Türkiye'de bulunan Suriyeli sayısı 14 bin iken 2017 yılının ilk yarısı itibariyle bu sayı üç milyonu geçmiş bulunmaktadır. Türkiye'de geçici korunma kapsamında bulunan Suriyeli mültecilerin 244.609'u, başka bir deyişle Türkiye'deki Suriyelilerin sadece \% 8'i, 10 ilde kurulan 23 geçici barınma merkezinde kalmaktadır. Geriye kalan \% 92'lik gibi büyük bir çoğunluk, geçici barınma merkezleri dışında Türkiye'nin farklı illerinde yaşamlarını sürdürmektedirler (GİGM, 2017).

GİGM'in (2017) Türkiye'de bulunan Suriyelilerin yaş ve cinsiyet verilerine göre, göç eden erkek ve kadın Suriyeli sayıları neredeyse eşittir. Türkiye'de bulunan Suriyelilerin 
1.410.080'i çocuklardan oluşmaktadır. Bir başka ifade ile Türkiye' deki Suriyelilerin yaklaşık yüzde 46'sı yani neredeyse yarısı, 0-18 yaş aralığındadır. Bunlar arasında okul çağında olan çocuk sayısı ise 1.030.388'dir. Başka bir ifadeyle, Türkiye'de bulunan Suriyeli mültecilerin yüzde 33’ü, yani üçte biri eğitim çağındadır. Bu veri, ülkelerinde eğitimlerini yarıda bırakarak gelen ve eğitimine devam etmesi gereken yüz binlerce Suriyeli çocuğun olduğunu göstermektedir. Dahası, 2011 yılından bu yana Türkiye'de 200 bini aşkın Suriyeli bebek doğmuştur (Erdoğan, 2015). Dolayısıyla Türkiye'de doğup büyüyen ve eğitim çağına yaklaşan büyük bir nüfus söz konusudur. Bu durum, Türkiye’nin Suriyeli çocuklara yönelik uzun vadeli eğitim politikaları geliştirmesini zorunlu kılmaktadır.

Birleşmiş Milletler Çocuk Yardım Fonu (UNICEF), Suriye’de yaşanan çatışmalardan önce ilkokula giden Suriyeli çocukların oranının \% 99, ortaokul eğitimi görenlerin oranının ise \% 82 olduğunu; ayrıca kız çocuklarının okullaşma oranının erkek çocukların oranına büyük ölçüde eşit olduğunu belirtmektedir. Bu istatistik, Suriye'nin savaştan önce eğitim çağındaki çocukların neredeyse tamamını eğitim sürecine katmayı başardığını göstermektedir. Ancak araştırma sonuçlarına göre savaştan sonra ülke içinde ve dışında 3 milyon Suriyeli çocuk eğitimini yarıda bırakmak zorunda kalmıştır (UNICEF, 2015).

Milli Eğitim Bakanlığı'nın (MEB) açıklamalarına göre 2017 yılı Mayıs ayı itibariyle, Bakanlığa bağlı okullarda öğrenim gören Suriyeli öğrenci sayısı 169.010; geçici eğitim merkezlerinde öğrenim gören Suriyeli öğrenci sayısı ise 294.112'dir (Yılmaz, 2017). Bu açıklama, 2016-2017 eğitim ve öğretim yılında Türkiye'de toplam 463.122 Suriyeli öğrencinin eğitim hizmetlerinden faydalandığını göstermektedir.

Türkiye'de okul çağındaki Suriyeli öğrencilere yönelik çıkarılan 2014/21 sayılı "Yabancılara Yönelik Eğitim-Öğretim Hizmetleri Genelgesi” kapsamında Suriyeli çocuklar, kampların içinde ve kampların dışında kurulan geçici eğitim merkezlerinde, bunun yanı sıra kamp dışında Bakanlığa bağlı devlet okullarında ve kendilerinin açtıkları özel okullarda eğitim hizmetlerinden faydalanabilmektedirler (MEB, 2014). Ayrıca yükseköğretim öğrencilerinin Türkiye'deki üniversitelerde öğrenim görmesi, yatay geçiş imkânları noktasında da önemli kolaylıklar sağlanmıştır.

Türkiye'nin diğer illerinde olduğu gibi Van ilinde de yaşamlarını sürdürmeye çalışan önemli bir Suriyeli mülteci kitlesi bulunmaktadır. Van iline göç eden Suriyeliler ilk olarak barınma sorunuyla karşılaşmaktadırlar. Bu temel sorunu bir şekilde çözmeyi başarabilen aileler, burayı kendilerine mesken etmişlerdir. Ancak barınma sorunu dışında onları bekleyen 
Van YYÜ Eğitim Fakültesi Dergisi (YYU Journal of Education Faculty), 2022:Şubat Özel Sayı 28-55,http://efdergi.yyu.edu.tr,

beslenme, uyum, işsizlik, dil farklılığı gibi çeşitli sorunlar bulunmaktadır. $\mathrm{Bu}$ sorunların giderilmesinde aileler ciddi sıkıntılar yaşamaktadırlar. Çocuk nüfusunun, Suriyeli nüfusunun yarısı gibi önemli bir oranını oluşturması ve dolayısıyla eğitim sorununun gündeme gelmesi, Türkiye'deki diğer illerde olduğu gibi Van ilinde de çözülmesi gereken önemli bir sorun haline gelmiştir.

Göç İdaresi Genel Müdürlüğü’nün Temmuz 2017 verilerine göre, Van ilinde 2.440 kayıtl1, 537 ön kayıt aşamasında olan toplam 2.977 Suriyeli yaşamaktadır. Van İl Göç İdaresi Müdürlüğü, Van'da bulunan kayıtlı Suriyelilerin demografik verilerini paylaşmadığından bu konu hakkında net bilgilere ulaşılamamıştır. Fakat Suriyelilerin Türkiye geneli demografik verilerinden yola çıkarak Van ilinde okul çağında yaklaşık 1000 Suriyeli çocuğun olduğu tahmin edilmektedir. Yapılan çalışmalar sonucu okul çağındaki Suriyeli çocukların devlet okullarına kayıt yapmasının önünde herhangi bir engel olmamasına karşın bu çocukların çok az bir kısmı devlet okullarında öğrenim görmektedir. Tablo 1'de 2016-2017 eğitim-öğretim yılında Van ilindeki okullarda öğrenim gören Suriyeli öğrencilerin ilçelere ve okul kademelerine göre sayıları verilmiştir.

Tablo 1. Van İlindeki Okullarda Kayıtlı Suriyeli Öğrenci Sayısı

\begin{tabular}{lccccc}
\hline İlçe & Ana sınıfi & İlkokul & Ortaokul & Lise & Toplam \\
\hline Edremit & 3 & 9 & 1 & 1 & $\mathbf{1 4}$ \\
Erciş & 2 & 6 & 1 & 1 & $\mathbf{1 0}$ \\
Gürpınar & - & - & 1 & - & $\mathbf{1}$ \\
İpekyolu & 3 & 11 & 3 & 1 & $\mathbf{1 8}$ \\
Özalp & - & 1 & - & - & $\mathbf{1}$ \\
Tuşba & 5 & 20 & 8 & 3 & $\mathbf{3 6}$ \\
\hline Genel Toplam & $\mathbf{1 3}$ & $\mathbf{4 7}$ & $\mathbf{1 4}$ & $\mathbf{6}$ & $\mathbf{8 0}$ \\
\hline
\end{tabular}

Kaynak: Van İl Milli Eğitim Müdürlüğü, 2017

Van İl Milli Eğitim Müdürlüğü’nden 2017 yılı Mayıs ayında alınan verilere göre, 20162017 eğitim-öğretim yılında Van ilindeki okullarda çoğunluğu Tuşba (36), İpekyolu (18) ve Edremit (14) ilçelerinde olmak üzere 80 Suriyeli öğrenci öğrenim görmektedir. Bu tablo, Van ilinde bulunan okul çağındaki yaklaşık 1000 Suriyeli çocuğun 80 tanesinin, başka bir ifadeyle sadece \% 8'inin devlet okullarında eğitimlerine devam ettiğini göstermektedir. Bu çocukların \% 92'si gibi büyük bir bölümünün eğitim dışı kalması önemli bir sorun olarak karşımızda durmaktadır. Dolayısıyla bu çalışmanın amacı, Türkiye'ye göç ettikten sonra Van iline yerleşen ve Van ilinde yaşamlarını sürdüren eğitim çağındaki Suriyeli mültecilerin yaşadıkları eğitim 
sorunlarını açığa çıkararak çözüm önerileri geliştirmektir. Bu genel amaç doğrultusunda aşağıdaki sorulara cevap aranacaktır:

1. Van ilinde yaşamlarını sürdüren eğitim çağındaki Suriyeli mülteci çocukların yaşadığı eğitim sorunlarına ve sunulan eğitimin niteliğine ilişkin katılımcıların görüşleri nelerdir?

2. Van ilinde yaşamlarını sürdüren eğitim çağındaki Suriyeli mülteci çocukların eğitim sürecinde yaşadıkları sorunların çözümüne ilişkin katılımcıların görüş ve önerileri nelerdir?

3. Van ilinde çeşitli nedenlerle eğitimlerine devam etmeyen okul çağındaki Suriyeli mülteci çocukların eğitime dâhil edilmesi noktasında katılımcıların görüş ve önerileri nelerdir?

\section{Yöntem}

\section{Araştırmanın Modeli}

Nitel yöntemle yapılan bu çalışma, bir durum (vaka) çalışmasıdır. Bu araştırmada nitel yönteminin kullanılmasının nedeni, bu yöntemin sosyal yaşam ve insan ile ilgili problemleri, gözlem, görüşme gibi tekniklerle sorgulayarak, anlamları ve ilişkileri parçadan bütüne açıklamaya imkân verebilmesidir (Neuman, 2014).

\section{Katılımcılar}

Araştırmanın çalışma grubunu, 2017 yılında Türkiye’ye göç etmiş ve Van ilinde yaşamlarını sürdüren eğitim çağındaki Suriyeli 13 (7 okula devam eden, 6 okula devam etmeyen) çocuk, 6 Suriyeli aile reisi, Van ilinde Suriyeli öğrencilerin 2016-2017 eğitimöğretim yılında öğrenim gördüğü okullardaki 8 öğretmen ve 5 okul müdürü, 2 il milli eğitim yöneticisi (bir il milli eğitim müdür yardımcısı, bir il milli eğitim şube müdürü), il milli eğitim müdürlüğünde görev yapan 7 maarif müfettişi, 1 sosyal yardımlaşma vakfi yöneticisi ve Van ilinde aktif olarak hizmet veren 4 sivil toplum kuruluşu ( 2 sendika, 2 yardım derneği) yöneticisi olmak üzere 46 kişi oluşturmaktadır. Katılımcıların görüşleri isim verilmeden aktarılacağı için her katılımcıya bir kod ve kodun yanında bir numara verilmiştir. Örneğin, Suriyeli çocuklar için Ç1, Ç2 ..., Suriyeli aile reisleri için A1, A2 .., öğretmenler için Ö1, Ö2 .., Yöneticiler için Y1, Y2..., Müfettişler için M1, M2..., STK ve Vakıf yöneticileri için ise S1, S2... şeklinde kodlar kullanılmıştır. 


\section{Verilerin Toplanması}

Araştırma konusu hakkında ilgili alan yazın taranarak ve Suriyelilerin eğitimi sorununa yönelik mevcut durumun tespit edilmesi amacıyla açık uçlu sorulardan oluşan bir soru havuzu hazırlanmıştır. Alanın uzmanı iki öğretim üyesi görüşleri doğrultusunda uygun sorulara karar verilmiştir. Ardından araştırmacı tarafından görüşme formları hazırlanmıştır. Van ilinde bulunan eğitim çağındaki Suriyeli aile reisleri ve çocuklarla, okula devam eden Suriyeli çocukların öğretmenleri ve okul yöneticileriyle, ayrıca il milli eğitim yöneticileri, vakıf ve sivil toplum kuruluşlarıyla yarı yapılandırılmış görüşmeler yapılmıştır.

Görüşme yöntemi ile katılımcılardan Suriyeli öğrencilerin eğitim sürecinde yaşadıkları sorunlar ve bu sorunların çözümü için talep, beklenti ve önerilerin, ayrıca araştırmaya katılan diğer katılımcıların da konu hakkındaki görüş ve düşüncelerinin neler olduğuna ilişkin derinlemesine veri toplanmaya çalışılmıştır. Suriyeli aile reisleri ve çocuklarla görüşmelerde tercüman aracılığıyla veriler toplanmıştır. Her bir görüşme yaklaşık 15-20 dakika sürmüştür. Yarı yapılandırılmış görüşme formunda yer alan sorular katılımcılara yöneltilip yanıt alınmıştır. Elde edilen yanıtlar, katılımcıların isimleri kodlanarak görüşme formuna kaydedilmişstir.

Araştırmanın verileri, 2017 yılında toplanmıştır. Ayrıca, araştırma sonucunda elde edilen verilerin ve çözüm önerilerinin araştırma başlığında belirtilen soruna katkılarının belirlenmesi amacıyla Van ilinde bulunan eğitim çağındaki Suriyeli çocukların 2017-2018 eğitim-öğretim y1lı ve 2018-2019 eğitim-öğretim yılı okula devam oranları tespit edilerek “Çalışmanın Söz Konusu Sorunu Çözmeye Yönelik Katkıları” başlığı altında verilmiştir. Dolayısıyla bu çalışma, ikinci yazarın birinci yazar danışmanlığında 2017 yılında yürüttüğü tez çalışmasından üretilmiş olup; çalışmaya 2018 yılı Ocak ayı ve 2019 yılı Şubat ayı Suriyeli çocukların eğitime devam verileri de eklenmiştir.

\section{Verilerin Analizi}

Araştırma verilerinin çözümlenmesinde, betimsel analiz yöntemi kullanılmıştır. Betimsel analiz, elde edilen ham verilerin önceden belirlenmiş temalara göre okuyucunun anlayabileceği şekilde (Altunışık, Coşkun, Yıldırım ve Bayraktaroğlu, 2001; akt. Duban ve Küçükyılmaz, 2008) özetlenmesine ve yorumlanmasına imkân sağlayan bir nitel veri analizi türüdür. $\mathrm{Bu}$ analiz türünde katılımcıların görüşlerini çarpıcı bir şekilde yansıtmak amacıyla doğrudan alıntılara sık sık yer verilir (Yıldırım ve Şimşek, 2008). 
Betimsel analiz sürecinde öncelikle araştırma sorularından veya katılımcıların görüşlerinden hareket edilerek ana temalar oluşturulmuştur. Sonra, oluşturulan ana temalara dayalı olarak veriler okunmuş ve düzenlenmiştir. Daha sonra düzenlenmiş olan veriler tanımlanmıştır. Bunun için gerekli yerlerde doğrudan alıntılara sıkça başvurulmuştur. Son olarak ise tanımlanmış olan veriler açıklanıp, ilişkilendirilmiş ve anlamlandırılmıştır (Yıldırım ve Şimşek, 2008). Araştırma verilerinin analizinde bir katılımcının bir soruyla ilgili birden fazla görüşü olduğu göz önünde bulundurularak katılımcı frekansı yerine görüş frekansına yer verilmiştir. Dolayısıyla da toplam frekansa yer verilmemiştir.

\section{Geçerlik ve Güvenirlik}

Hazırlanan görüşme formlarının anlaşılırlı̆̆ının ve uygulanabilirliğinin kontrol edilmesi amacıyla biri Türkçe biri Eğitim Yönetimi alanında öğretim üyesi olan iki uzman görüşüne başvurulmuş olup dönütler doğrultusunda gerekli düzenlemeler yapılarak formlara son şekli verilmiştir.

Araştırmada veri toplama sürecinde görüşmeler, katılımcılardan izin alınarak ses kayıt cihazıyla kaydedilmiş olup; bu kayıtlar sonradan araştırmacı tarafından görüşme formlarına yazılı olarak aktarılmıştır. Kayıtların forma aktarılmasından sonra cevapların teyidi amacıyla katılımcılara verdikleri cevaplar gösterilmiş ve katılımcı teyidi yoluyla onayları alınmıştır. Bunun yanı sıra, elde edilen veriler ayrıntılı bir şekilde raporlanmış, doğrudan alıntılara sıkça yer verilmiş, veri toplama ve veri analizi ile ilgili ayrıntılı bilgilere yer verilmiştir. Böylelikle araştırmanın geçerliği ve güvenirliği artırılmıştır.

\section{Bulgular ve Yorum}

\section{Van İlinde Eğitimine Devam Eden Suriyeli Çocuklara İlişkin Bulgular}

$\mathrm{Bu}$ tema başlığı altında Van ilinde yarıda kalan eğitimine devam eden Suriyeli öğrencilerin okullarda yaşadıkları sorunlara, bu sorunların çözümüne yönelik öğretmen ve okul yöneticilerinin aldıkları tedbirlere, Suriyeli öğrencilerin kendilerine sunulan eğitim hizmetleri noktasındaki talep ve beklentilerine ve okullarda yaşanan bu sorunların çözümüne yönelik il yöneticileri, müfettişler, okul yöneticileri ve öğretmenlerin önerilerine ilişkin elde edilen verilere yer verilmiştir. 
Van YYÜ Eğitim Fakültesi Dergisi (YYU Journal of Education Faculty), 2022:Şubat Özel Sayı 28-55,http://efdergi.yyu.edu.tr,

Van ilinde yarıda kalan eğitimine devam eden Suriyeli öğrencilerin okullarda yaşadıkları sorunlara ilişkin Suriyeli aile reislerinin ve çocukların, öğretmenlerin ve okul yöneticilerinin görüşleri aşağıdaki Tablo 2’de verilmiştir.

Tablo 2. Okulda Yaşanan Sorunlara İlişkin Katılımcıların Görüşleri

\begin{tabular}{lccccc}
\hline Görüşler & Çocuk & Aile & Öğrt. & Yön. & f \\
\hline Dil (iletişim) sorunu & 2 & 2 & 8 & 6 & 18 \\
Okul kültürüne uyum sorunu & - & - & 5 & 4 & 9 \\
Maddi sorunlar & 7 & 1 & - & 1 & 9 \\
Yalnızlık ve sessizlik & 3 & 2 & 2 & - & 7 \\
Yabancılık ve utangaçlık & 3 & - & 3 & - & 6 \\
Derslerde başarısılık & 2 & - & 2 & - & 4 \\
Öğrencilerin hazırbulunuşluklarının tespit & - & - & 1 & 1 & 2 \\
edilmeden eğitime dâhil edilmesi & - & - & 1 & - & 1 \\
Dişlanma & - & - & 1 & - & 1 \\
Psikolojik sorunlar & - & 1 & - & - & 1 \\
Öğretmenlerin ilgisiz olması & & & & \\
\hline
\end{tabular}

Tablo 2’de görüldüğü üzere okulda yaşanan sorunlar noktasında görüşülen 7 çocuktan 2'si (Ç7, Ç8), çocukları okula devam eden 3 aile reisinden 2'si (A1, A2) ayrıca öğretmen ve yöneticilerin neredeyse hepsi okulda yaşanan en öncelikli sorunun dil sorunu olduğunu dile getirmişlerdir. Katılımcı çocuklar dil farklılığından kaynaklı iletişim sıkıntılarının yaşadığını, Türkçeyi az bildiklerinden dersleri anlamakta sıkıntılar yaşadıklarını ifade etmişlerdir. Öğretmen ve yöneticiler ise öğrencilerde gözlemlenen en ciddi sorunun iletişim sorunu olduğunu, bu sorunun yaşanan diğer bütün sorunlara yol açtığını ifade etmişlerdir. Öğretmen ve yöneticilerin yarısı dil ve kültür farklılığından dolayı öğrencilerin okul kültürüne ve ortamına alışamadıkları görüşündedirler. Yöneticilerden biri bu yöndeki görüşünü "Suriyeli ögrencilerin okulda yaşadığı sorunların başında dil yani iletişim sorunu geliyor. Çevresiyle ilişki kurmak isteyen fakat iletişim kurmakta zorlanan çocuklarda bu sefer uyum sorunu baş gösteriyor (Y1)” şeklinde dile getirmiştir.

Tablo 2’ye göre çocukların bazılarının yalnızlık, yabancılık, utangaçlık, başarısızlık ve sessiz olma gibi sorunlar yaşadıkları görülmektedir. Öğrencilerden 2‘si (Ç7, Ç10) dil farklılığından dolayı derste işlenen konuları çok öğrenemediklerini ve sınavlarda başarısız olduklarını dile getirirken; 3'ü (Ç11, Ç12, Ç13) derste öğretmenlerini tam anlayamadıkları için kendilerini yalnız ve yabancı hissettiklerini dile getirmişlerdir. Bir öğretmen ise bu konudaki görüşünü “...derste benim söylediklerimi çok anlamıyorlar ve sınavlarda başarısız oluyorlar. Ben de onların dilini konuşamıyorum bu yüzden yabancllık çekiyorlar. Bu da sürekli sessiz 
olmalarına ve utangaç davranmalarına neden oluyor (Ö8)” şeklinde dile getirmiştir. Bunun yanı sıra katılımcı aile reislerinden biri (A1) öğretmenlerin çocuklarla çok ilgilenmediğini ifade ederken; öğretmenlerden biri (Ö2) çocukların farklı dil ve kültürden dolayı kendilerini dışlanmış hissettiklerini, başka bir öğretmen (Ö4) ise yaşanan bu sorunların tümünün çocuklarda psikolojik sorunlara yol açtığını ifade etmiştir.

Van ilinde yarıda kalan eğitimine devam eden Suriyeli öğrencilerin okullarda yaşadıkları sorunların giderilmesine yönelik öğretmenlerin ve okul yöneticilerinin aldıkları tedbirlere ilişkin görüşleri Tablo 3’te verilmiştir.

Tablo 3. Okulda Yaşanan Sorunların Giderilmesine Yönelik Alınan Tedbirler

\begin{tabular}{lccc}
\hline Görüşler & Öğrt. & Yön. & f \\
\hline Oryantasyon (uyum) çalışmaları & 5 & 3 & 8 \\
Etkinliklere katılımlarını sağlama & 3 & 2 & 5 \\
Diğger öğrencilerden empati kurmalarını isteme & 3 & 2 & 5 \\
Öğrencilerle ekstra zaman harcama & 2 & 2 & 4 \\
Okuma-yazma çalışmaları & 2 & - & 2 \\
Seminerlere katılma & 2 & - & 2 \\
Akran danışmanlığı & 2 & - & 2 \\
Ailelerle görüşmeler & 1 & - & 1 \\
Sinıf mevcutlarında değişiklikler & - & 1 & 1 \\
\hline
\end{tabular}

Verilen tabloya göre, katılımcı okul yöneticileri ve öğretmenlerin yarısından fazlası Suriyeli öğrencilerin okula, yeni bir kültüre ve arkadaş çevresine alışmalarını hızlandırmak için rehberlik öğretmenleri aracılığıyla oryantasyon çalışmaları yaptıklarını dile getirmişlerdir. Öğretmenlerden 3'ü (Ö2, Ö5, Ö8) sınıf içi ders etkinliklerinde ve sınıf dışı etkinliklerde göç eden öğrencilere sık sık görev verdiklerini, onları sürekli tören ve kutlamalara dâhil ettiklerini, diğer öğrencilerine onlarla sürekli oynamaları gerektiğini söylediklerini, kendilerini onların yerine koymaları gerektiğini söylediklerini ifade ederken; okul yöneticilerinden 2'si (Y4, Y5) yine bu yönde görüş bildirerek her fırsatta öğretmenlerin bu çocukların etkinliklere katmaları gerektiğini söylediklerini ifade etmişlerdir. Bir öğretmen bu konudaki aldıkları tedbirlere ilişkin görüşünü "Sinıftaki ögrrencimin sorun yaşamaması ve diğer öğrencilere onunla empati kurmaları için yönlendirmelerde bulundum. Ayrıca topluma ve sınıfa alışması için her türlü etkinliğe katılımını ve böylece sınıfla kaynaşmasını sağladım (Ö2)” sözleriyle ifade etmiştir.

Tabloda görüldüğ̈̈ üzere, öğretmenlerden 2'si (Ö2, Ö4) öğrencilere daha çok fayda sağlayabilmek için ilçe milli eğitim müdürlüğünün Suriyeli öğrencilerin öğretmenleri için düzenlediği seminerlere katıldığını dile getirirken; diğer 2'si (Ö3, Ö6) öğrencilerin sorunlarını 
giderebilmek ve onlara faydalı olmak için akran danışmanlığı yönteminden faydalandıklarını dile getirmişlerdir. Bunun yanı sıra öğretmenlerden biri (Ö6) sorunların giderilmesi noktasında ailelerle görüşmeler yaptıklarını ifade ederken; yöneticilerden biri (Y5) Suriyeli öğrencilerin bulunduğu sınıflarda sınıf öğretmenlerinin iş yükünü hafifletmek ve göç eden öğrenciyle daha çok ilgilenebilmesi adına sınıf mevcutlarında değişiklikler yaptıklarını ifade etmiştir.

Suriyeli aile reislerinin ve Van ilinde yarıda kalan eğitimine devam eden Suriyeli öğrencilerin eğitimleri noktasında yetkililerden talep ve beklentilerine ilişkin görüşleri Tablo 4’te verilmiştir.

Tablo 4. Suriyelilerin Eğitimlerine Yönelik Talep ve Beklentileri

\begin{tabular}{lccc}
\hline Görüşler & Çocuk & Aile & f \\
\hline Maddi sorunların (giyim, araç-gereç) giderilmesi & 7 & 3 & 10 \\
Gelecek için iyi bir eğitim alınması & 5 & 2 & 7 \\
Eğitimlerinin sürekliliğinin sağlanması & 7 & - & 7 \\
Türkçe öğrenilmesi & 4 & - & 4 \\
Eğitim dilinin Arapça olması & 3 & - & 3 \\
Öğretmenlerin daha ilgili olması & 1 & 2 & 3 \\
Sadece Suriyelilerin olduğu okulların açılması & 1 & 1 & 2 \\
\hline
\end{tabular}

Tablo 4'e göre, eğitimlerine yönelik yetkililerden talep ve beklentilerinin neler olduğu noktasında görüşleri alınan 7 çocuk ve 3 aile reisinin tümü okul dışında maddi sorunlar yaşadıklarını, ailedekilerin iş bulmada zorlandıklarını, çalışanlar olsa dahi elde edilen gelirin yeterli olmadığını ve yaşanan bu sıkıntıların da eğitimlerine yansıdığını ifade etmişlerdir. $\mathrm{Bu}$ noktada Suriyeliler, ihtiyaçların giderilmesi noktasında maddi yardım talebinde bulunmaktadırlar.

Tablo 4’te görüldüğü üzere görüşülen Suriyeli öğrencilerin tamamı, yarıda kalan eğitimlerine burada devam etmek istediklerini dile getirmiş ve eğitimlerinin sürekli devam etmesi talebinde bulundukları, özellikle görüşülen aile reislerinden 2'si (A2, A6) okul ortamının çocuklar için koruyucu bir yer olduğu, çocukları kötü ortamlardan alıkoyduğu yönünde görüş bildirmişlerdir. Aile reislerinden biri bu yöndeki görüşünü “...okul çok önemli çocuklar yeter ki okula gitsinler. Çünkü onları eğitecek ögretmenleri var, temiz arkadaş çevresi var (A2)" ş̧eklinde dile getirmiştir. Ayrıca çocuklardan neredeyse tamamı, yarıda kalan eğitimlerine zor da olsa burada devam ettiklerini, okulu çok sevdiklerini ve gelecekleri için iyi bir eğitim almak istediklerini ifade etmişlerdir.

Suriyeli çocukların ve aile reislerinin Suriyelilerin eğitimi noktasındaki talep ve beklentilerine ilişkin görüşlerinden biri aşağıda verilmiştir: 
Van YYÜ Eğitim Fakültesi Dergisi (YYU Journal of Education Faculty), 2022:Şubat Özel Sayı 28-55,http://efdergi.yyu.edu.tr,

“Aileme maddi yardımlarda bulunulmasını istiyorum. Okulda öğrencilerin giydiği elbiseyi alamadım ve yeterli eşyam ve çantam yok. Bu konuda yardımcı olunmasını istiyorum. Ama okul müdürümüz seneye bir şey almamamı istedi, okul klyafetini bana onların vereceklerini söyledi (Ç7)."

Van ilinde yarıda kalan eğitimine devam eden Suriyeli öğrencilerin eğitiminde yaşanan sorunların çözümüne yönelik öğretmenlerin, okul ve il yöneticilerinin ve müfettişlerin önerileri Tablo 5’te verilmiştir.

Tablo 5. Eğitimde Yaşanan Sorunların Çözümüne Yönelik Öneriler

\begin{tabular}{lcccc}
\hline Öneriler & Öğrt. & Yön. & Müf. & f \\
\hline Rehberlik (uyum) çalışmaları artırılmalı & 4 & 6 & 6 & 16 \\
Türkçe dil kursu verilmeli & 6 & 3 & 4 & 13 \\
Sosyalleşme çalışmaları (etkinlikler) yapılmalı & 3 & 5 & 4 & 12 \\
Eğitim (malzeme, giyim) ihtiyaçları karşılanmalı & 3 & 3 & 3 & 9 \\
Öğretmenler öğrencilerle ekstra vakit geçirmeli & 3 & 3 & 1 & 7 \\
Arapça ve Kürtçe bilen öğretmenler ders vermeli & 2 & 2 & 1 & 5 \\
Öğrenciler kaynaştırma eğitimine tabi olmalı & - & 1 & 2 & 3 \\
Hazırbulunuşlukları tespit edilerek sınıflara & 1 & - & 1 & 2 \\
dağıtılmalı & 1 & 1 & - & 2 \\
Uzmanlar tarafından psikolojik destek sunulmalı & - & - & 1 & 1 \\
Farklı programlar uygulanmalı & - & 1 & - & 1 \\
Sınıf mevcutları düşürülmeli & 1 & - & - & 1 \\
Ailelerle görüşmeler yapılmalı & - & 1 & - & 1 \\
Okulda çalışan herkese hizmet içi eğitim verilmeli & & & \\
\hline
\end{tabular}

Tablo 5’e göre okulda yaşanan sorunların çözümüne yönelik önerilerin neler olduğu konusunda görüşleri alınan 8 öğretmenin yarısı, 7 il ve okul yöneticilerinin ve ayrıca 7 müfettişin neredeyse tamamı, göç eden öğrencilerin yeni çevreye henüz alışamadıklarını, okulda uyum sorunu yaşamaya devam ettiklerini bu yüzden okulda bu çocuklara yönelik rehberlik çalışmalarına daha çok ağırlık verilmesi gerektiğini; ayrıca katılımcıların neredeyse yarısı, sınıf içerisinde veya dışında bu çocukların oyunlara, tören ve etkinliklere dâhil edilerek sosyalleşmelerinin sağlanması gerektiğini ifade etmişlerdir. Bir yönetici, bu konudaki önerisini “öğrencilerin uyum sorunlarını ortadan kaldırmak için bu öğrencilere yönelik sosyal aktiviteler düzenlenmeli, ayrıca Suriyeli eğitmenlerin de yer aldı̆̆g psikolojik danışmanlar öncülüğünde çocukların uyumuna yönelik çalışmalar ve projeler üretilmeli (Y7)” ş̧eklinde dile getirmiştir. Öğretmenlerden 3'ü (Ö3, Ö5, Ö8), yöneticilerin yarısına yakını ve müfettişlerden biri (M3), öğretmenlerin göç eden öğrencilerle daha fazla vakit geçirmesi gerektiğini, onlara daha fazla zaman harcayarak uyumları konusunda yardımcı olmaları gerektiğini, "bu gibi yakın 
Van YYÜ Eğitim Fakültesi Dergisi (YYU Journal of Education Faculty), 2022:Şubat Özel Sayı 28-55,http://efdergi.yyu.edu.tr,

ilişkilerin göç eden öğrencilerin özgüvenini artıracağını ve yabancılık, yalnızlık gibi olumsuz hallerinin ortadan kalkmasına yardımcı olacă̆ını (Ö8)” ifade etmişlerdir. Ayrıca yöneticilerden biri (Y5) okulda görev yapan herkese göç eden öğrencilerin uyumu hakkında eğitimler verilmesi gerektiğini dile getirmiştir.

Tabloda görüldüğü üzere katılımcı öğretmenlerin 3/4’ü, yönetici ve müfettişlerin ise yarısına yakını, Suriyeli öğrencilerin eğitiminde rastlanan en önemli sorun olan dil sorununun giderilmesi gerektiğini, böyle bir sıkıntı olduğu sürece eğitim ve öğretimin göç eden öğrencilere çok şey katmayacağını, bu noktada okul bünyesinde Türkçe dil kursları veya okuma-yazma kurslarının açılması gerektiğini ve buna çok önem verilmesi gerektiğini ifade etmişlerdir.

Van ilinde yarıda kalan eğitimine devam eden Suriyeli öğrencilere okulun katkılarına ilişkin Suriyeli aile reisleri ve çocukların, öğretmenlerin ve okul yöneticilerinin görüşleri Tablo 6’da verilmiştir.

Tablo 6. Okulun Suriyeli Öğrencilere Katkılarına İlişkin Katılımcıların Görü̈şleri

\begin{tabular}{lccccc}
\hline Görüşler & Çocuk & Aile & Öğrt. & Yön. & f \\
\hline Sosyalleşmenin sağlanması & 5 & 3 & 3 & 4 & 15 \\
Arkadaş çevresinin oluşması & 7 & 3 & 3 & 2 & 15 \\
Yeni bir dilin (Türkçe) öğrenilmesi & 3 & 3 & 2 & 4 & 12 \\
Eğitime devam edebilme & 4 & 1 & 3 & 2 & 10 \\
Yeni bir çevreye alışmalarını sağlama & - & 3 & 2 & 1 & 6 \\
Okuldaki arkadaşların ailelerinin kendilerine & 1 & 3 & - & - & 4 \\
yardımlarda bulunması & - & - & 3 & - & 3 \\
Ülkenin kültürünü tanıma & - & - & 2 & 1 & 3 \\
Psikolojik sorunlardan kurtulma & - & - & 1 & - & 1 \\
Aidiyet duygusu kazanma & - & - & - & 1 & 1 \\
Güvenli bir ortamda hissetme & & & & & \\
\hline
\end{tabular}

Verilen tabloya göre okulun Suriyeli öğrencilere katkılarının neler olduğuna yönelik görüşme yapılan eğitimine devam eden 7 çocuktan neredeyse tamamı, çocuğu okula giden 3 aile reisinin tümü, 8 öğretmenden 3’ü (Ö3, Ö4, Ö5) ve 5 okul yöneticisinin neredeyse tamamı okulun çocukların sosyalleşmesi açısından önem arz ettiğini, topluma yabancılaşmalarını ve yalnızlaşmalarını engellediğini ifade etmişlerdir. Ayrıca katılımcı çocukların ve aile reislerinin tamamı, öğretmen ve yöneticilerin neredeyse yarısı bir çocuğun toplumun değerlerini benimsemesi, topluma dâhil olması ve sosyalleşmesi açısından arkadaş ortamının önemine değinerek okul ortamının göç eden öğrencilere yeni arkadaş ve arkadaşlıklar kazandırdığını dile getirmişlerdir. Katılımcı çocuklardan biri edindiği arkadaşlıklar nedeniyle memnuniyetini 
“...okula başlamadan önce evde çok sıkılıyordum ama okula başlayınca çok arkadaşım oldu. Birlikte çok güzel vakit geçiriyoruz (Ç7)” sözleriyle ifade etmiştir.

Tablo 6’da görüldüğü üzere katılımcı çocuklardan 3’ü (Ç8, Ç9, Ç13) ve aile reislerinin tamamı, okulun katkılarından bir diğerinin Türkçeyi öğrenmeleri olduğunu ifade etmişlerdir. Katılımcı çocuklar, yeni bir dil öğrenmenin kendilerine keyif verdiğini, öğrenmeyi çok istediklerini ayrıca Türkçeyi öğrenmenin yaşadıkları önemli sorunlardan biri olan iletişim sorununu kısmen çözdüğünü dile getirmişlerdir. Bunun yanı sıra öğretmenlerden 2'si (Ö5, Ö6) ve okul yöneticilerinin tamamına yakını, çocukların Türkçe dilini öğrenmeye başladıktan sonra yaşanan sorunların daha halledilebilir hale geldiğini, çocukların bu noktada özgüvenlerinin de arttığını ifade etmişlerdir. Bir yönetici bu noktada “...göç eden öğrencilerle başlangıçta dil farklılığından ve iletişimsizlikten dolayı çok sorunlar yaşadık. Bu sorun oldukça hiçbir katkımızın olmayacağını düşünerek dil kurslarına ă̆ırlık verdik. Dil gelişimi sağlandıkça eğitimlerinde daha faydalı olmaya başladık (Y1)” şeklinde görüş belirtmiştir.

\section{Van İlinde Eğitimine Devam Etmeyen Okul Çağındaki Suriyeli Çocuklara İlişkin Bulgular}

Bu tema başlığı altında Van ilinde yaşamlarını sürdüren okul çağındaki Suriyeli çocukların okula devam etmeme nedenlerine, çocukların eğitime devam etmeme nedenlerinin giderilmesine ilişkin talep ve beklentilerine, ayrıca eğitimlerine devam etmeyen Suriyeli çocukların eğitime dâhil edilmesine yönelik katılımcıların önerilerine ilişkin elde edilen verilere yer verilmiştir.

Van ilinde yaşamlarını sürdüren okul çağındaki Suriyeli çocukların eğitimlerinde devam etmeme nedenlerine ilişkin Suriyeli aile reisleri ve çocukların görüşleri Tablo 7'de verilmiştir.

Tablo 7. Suriyeli Çocukların Eğitimlerine Devam Etmeme Nedenleri

\begin{tabular}{lccc}
\hline Görüşler & Çocuk & Aile & f \\
\hline Bir işte çalışma zorunluluğu & 3 & 2 & 5 \\
Vatandaşlık kimliğinin olmaması & 3 & - & 3 \\
Kalacak bir evin olmaması & 2 & - & 2 \\
Sürekli mekân değiştirme & 1 & 1 & 2 \\
Dil farklılığı & 2 & - & 2 \\
Okul için gerekli malzemelerin olmaması & 1 & - & 1 \\
Suriyelilere eğitim verilmediği düşüncesi & 1 & - & 1 \\
Ne yapılacağının bilinmemesi & 1 & - & 1 \\
\hline
\end{tabular}

Tablo 7’ye göre Van ilinde yarıda kalan eğitimlerine devam etmeyen okul çağındaki Suriyeli çocukların eğitimlerine devam etmeme nedenlerine ilişkin görüşme yapılan 6 çocuğun 
Van YYÜ Eğitim Fakültesi Dergisi (YYU Journal of Education Faculty), 2022:Şubat Özel Sayı 28-55,http://efdergi.yyu.edu.tr,

yarısı ve çocuğu okula gitmeyen 3 aile reislerinden 2'si (A3, A5) maddi sorunlar nedeniyle okula gidilmediğini dile getirmişlerdir. Özellikle çocuklar okula gitmeyi çok istediklerini ancak barınma ve beslenme gibi temel ihtiyaçlarını gideremediklerini bu yüzden de herhangi bir işte çalışıp geçimlerini sağlamaya çalıştıklarını ifade ederken; ailelerden ikisi kalacak bir ev bulamadıklarını, ihtiyaçların karşılanması için kendilerinin düzenli bir iş bulamadıklarını bu yüzden de hanedeki herkesin çalışmak zorunda olduğunu ifade etmişlerdir. Çocuklardan biri bu konudaki görüşünü “Ben, annem, iki kardeşim ve nenem burada yaşıyoruz. Okula gitmeyi istiyorum ancak onlara bakacak kimse yok. Para kazanmam lazım (Ç3)" şeklinde dile getirmiştir. Ayrıca çocuklardan biri (Ç2), okula gitmek için gerekli ders araç gereçleri ve kıyafetinin olmadığını, maddi sorunlar nedeniyle bunları temin etmekte zorlandıkları nedeniyle okula gitmek istemediğini ifade etmiştir.

Tabloda görüldüğü üzere Suriyeli çocukların okula gitmeme nedenleri arasında vatandaşlık kimliğinin olmaması dikkat çeken bir diğer nedendir. Çocuklardan Ç1 ve Ç2, Van iline yerleştikten çok sonra kimlik için müracaat ettiklerini fakat henüz çıkmadığını ifade ederlerken; Ç6 bu konudaki görüşünü "Buraya daha yeni geldik birkaç ay oldu. Kimliğimiz yok ama babam kimliğimi çıkarıp beni seneye okula gönderecek” şeklinde ifade etmiştir.

Van ilinde yaşamlarını sürdüren okul çağındaki Suriyeli çocukların eğitimlerine devam etmeme nedenlerinin giderilmesine ilişkin Suriyeli aile reisleri ve çocukların talep ve beklentileri Tablo 8'de verilmiştir.

Tablo 8. Eğitime Devam Etmeme Nedenlerinin Giderilmesine Yönelik Talepler

\begin{tabular}{lccc}
\hline Görüssler & Çocuk & Aile & f \\
\hline Maddi yardım & 5 & 2 & 7 \\
Kalıcı bir eve sahip olma & 2 & 2 & 4 \\
Okul eşyalarının alımında yardım & 3 & 1 & 4 \\
Eğitimdeki dil sorununun çözülmesi & 3 & - & 3 \\
Sadece Suriyelilerin olduğu okulların olması & - & 2 & 2 \\
Ailedekilere iş imkânı sağlanması & 2 & - & 2 \\
Vatandaşlık kimliği verilme sürecinin hızlandırılması & 2 & - & 2 \\
\hline
\end{tabular}

Tablo 8’e göre, Suriyeli aile reisleri ve çocukların eğitime devam etmeme nedenlerinin giderilmesine yönelik talepleri arasında en önemlisi olarak maddi yardım talepleri olmuştur. Görüşme yapılan 6 çocuk ve 3 aile reisinin tamamına yakını, tüm sorunların kaynağını teşkil eden maddi sorunların giderilmesi yönünde talepte bulunmuşlardır. Katılımcılar, eğitimden önce barınma ve beslenme ihtiyaçlarının karşılanması gerektiği, bunların halledilmemesi durumunda eğitime devam etme noktasında sıkıntılar olacağını bundan dolayı Suriyeli ailelerin 
Van YYÜ Eğitim Fakültesi Dergisi (YYU Journal of Education Faculty), 2022:Şubat Özel Sayı 28-55,http://efdergi.yyu.edu.tr,

bu yöndeki ihtiyaçlarının karşılaması yönünde görüş bildirmişlerdir. Bunun yanı sıra çocuklardan 2'si (Ç3, Ç4) ailecek maddi sorunlar yaşadıklarını, ailedekilerin sürekli çalışacak bir işlerinin olmadığını ve eğitimlerinin ikinci planda kaldığını bu yüzden ailedeki bireylere iş imkânının sağlanması talebinde bulunmuşlardır.

Van ilinde yaşamlarını sürdüren okul çağındaki Suriyeli çocukların eğitimlerine devam etmeme nedenlerinin giderilmesine ilişkin Suriyeli aile reisleri ve çocukların talep ve beklentilerinden bazıları aşağıda verilmiştir:

"Okula gitmeyi çok istiyorum. Burada uzun zamandan beridir yaşlyoruz Türkçeyi de biraz ögrendim. Belki dersleri biraz anlamayabilirim ama öğretmenlerimiz bizimle ilgilenirlerse ben çok çalışırım eksikliklerimi gideririm (Ç1).”

“Kalıcı, sürekli yer değiştirmeyeceğimiz bir evimiz olsun istiyoruz. Kalıcı bir evimiz olursa bende okula gidebilirim. Sadece Suriyelilerin olduğu okullara da gitmek isterim diğerlerine de. Türkçe de öğrenebilirim biraz öğrendim zaten. Çok çalışırım (Ç4). ”

Van ilinde eğitimlerine devam etmeyen okul çağındaki Suriyeli çocukların eğitime dâhil edilmelerine ilişkin öğretmen, okul ve il yöneticileri, müfettişler, STK ve vakıf yöneticilerinin önerileri Tablo 9'da verilmiştir.

Tablo 9. Eğitimlerine Devam Etmeyen Suriyeli Çocukların Eğitime Dâhil Edilmesine Yönelik Katılımcıların Önerileri

\begin{tabular}{lccccc}
\hline Görüşler & Öğrt. & Yön. & Müf. & STK & f \\
\hline Yeterli donanıma sahip öğretmenler seçilmeli & 3 & 3 & 3 & 5 & 14 \\
Anadilde eğitim verilmeli & 4 & 4 & 3 & 3 & 14 \\
Maddi yardımlarda bulunulmalı & 2 & 3 & 4 & 4 & 13 \\
Barınma ihtiyaçları giderilmeli & 1 & 3 & 4 & 4 & 12 \\
Sadece Suriyelilerin olduğu okullar açılmalı & 2 & 2 & 4 & 4 & 12 \\
Türkçeyi öğrenmeleri sağlanmalı & 5 & 2 & 3 & 1 & 11 \\
Uzmanlar tarafından uyum çalışmaları & 3 & 3 & 2 & 2 & 10 \\
yapılmalı & 1 & - & 3 & 5 & 9 \\
$\begin{array}{l}\text { Eğitim için gerekli ihtiyaçlar giderilmeli } \\
\text { Sağlıklı tespitler yapılarak veriler toplanmalı }\end{array}$ & - & 2 & 4 & 3 & 9 \\
$\begin{array}{l}\text { Hazırbulunuşluk düzeyleri tespit edilmeli } \\
\text { Ailelerle görüşmeler yapılmalı }\end{array}$ & 3 & 1 & 3 & - & 7 \\
Tarih ve kültürlerine yönelik çalışmalar & 1 & 1 & 2 & 2 & 6 \\
yapılmalı & 1 & 1 & 3 & - & 5 \\
Belli koşullardan sonra devlet okullarına & 3 & 1 & - & - & 4 \\
alımmalı & & & & &
\end{tabular}


Çalışmalar koordineli şekilde tek elden yönetilmeli

Sosyal yaşam alanları oluşturulmalı

Mesleki eğitime yönlendirmeler yapılmalı

Suriyeli öğretmenler görevlendirilmeli

Suriyelilerin tümü bir bölgeye toplanmalı

Farklı bir program geliştirilmeli

Aile ve çocuklara psikolojik destekler sunulmalı

Taşımalı eğitim desteği sunulmalı

Eğitimlerde görev olacak idareci, öğretmen

ve personellere seminerler verilmeli

$\begin{array}{lllll}- & 1 & 2 & 1 & 4 \\ 1 & 1 & - & 2 & 4 \\ - & 1 & 1 & 1 & 3 \\ - & 2 & - & 1 & 3 \\ - & - & 3 & - & 3 \\ - & 1 & 1 & - & 2 \\ - & 1 & - & 1 & 2 \\ - & - & - & 1 & 1 \\ - & 1 & - & - & 1\end{array}$

Tablo 9’da görüldüğü üzere katılımcıların okul çağındaki Suriyeli öğrencilerin eğitime dâhil edilmesi yönündeki önerilerinden en sık dile getirilenin yine dil sorunundan kaynaklı bir önerinin olduğu görülmektedir. Katılımcılar, eğitime devam eden hali hazırdaki öğrencilerin farklı bir dilden dolayı iyi bir eğitim alamadıkları ve hali hazırdaki öğretmenlerin bu konuda yetersiz oldukları düşüncesinden yola çıkarak Suriyeli öğrencilere anadillerinde eğitim verebilecek donanıma sahip eğitmenlerin eğitim vermesi gerektiği önerisinde bulunmuşlardır. Bunun yanı sıra Suriyeli ailelerin maddi sorunlar yaşadıkları ve dolayısıyla eğitim probleminden önce barınma ve beslenme gibi problemlerin çözülmesi gerektiği düşüncesi katılımcıların en sık tekrarladığı önerilerdendir.

Katılımcıların önerilerine göre, Suriyeli öğrencilerin devlet okullarına alınmadan önce eğitim seviyelerinin ve hazırbulunuşluk düzeylerinin tespit edilmesi gerekir. Bu öğrencilerin eğitim öncesi gerekli ihtiyaçlarının giderilmesi ve öğrencilerin belli koşulları (dil, uyum vb.) sağladıktan sonra sınıf ortamına alınmaları gerekmektedir. Bunun yanı sıra Suriyeli çocukların eğitiminde görev alacak öğretmen, okul idarecileri ve personellerin hizmet içi eğitimlere tabi tutulmaları gerektiği, çocukların eğitimleri noktasındaki çalışmaların tek elden yönetilerek gerekirse sivil toplum kuruluşlarının da katkıları alınarak koordineli bir şekilde yapılması gerektiği ayrıca bu çocukların aileleriyle de sık sık görüşmeler yapılması gerektiği öneriler arasında dikkat çekmektedir.

Van ilinde eğitimlerine devam etmeyen okul çağındaki Suriyeli çocukların eğitime dâhil edilmelerine ilişkin katılımcıların önerilerinden bazıları aşağıda verilmiştir:

"Suriyeli göçmenlerin belli yerlerde iskânı sağlanarak en azından büyük bir çoğunluğunun takibi bu şekilde yapılabilir. Ayrıca okul çağındaki çocuğu okula 
Van YYÜ Eğitim Fakültesi Dergisi (YYU Journal of Education Faculty), 2022:Şubat Özel Sayı 28-55,http://efdergi.yyu.edu.tr,

gitmeyen ailelere, maddi yardım yapılma şartının çocuklarını okula göndermelerine bağlanabilir (M2).”

"Milli eğitim müdürlükleri, belediyeler ve sivil toplum kuruluşlart ile ortaklaşa çalışmalar yürütülmelidir. Bu noktada öncelikle fizibilite çalışmaları, kaynak ve personel temini ardından fiziki koşullar sağlanarak bu çocukların bir an önce eğitime dâhil edilmesi gerekmektedir (S2).”

\section{Tartışma ve Sonuç}

Van ilinde elde edilen verilere göre okul çağında 1000'e yakın Suriyeli bulunmasına rağmen bunlardan sadece 80 tanesi yani \% 8’i devlet okullarında eğitim ve öğretim faaliyetlerinden faydalanmaktadır. Bu çocukların \% 92'si eğitimlerine devam etmemektedirler. Elde edilen bulgularda bu çocukların okula gitmeyi çok istemelerine rağmen maddi imkânsızlık, sürekli yer değiştirme, dil sorunu gibi çeşitli nedenlerle okula gidemedikleri sonucuna ulaşılmıştır.

Van ilinde bulunan eğitim çağındaki Suriyeli çocukların eğitimi sorununun iki farklı başlık halinde ele alınıp değerlendirilmesi gerekmektedir. Birincisi, hali hazırda devlet okullarının herhangi birinde öğrenim gören Suriyeli çocukların eğitimi sorunu; ikincisi ise çeşitli nedenlerde eğitimine devam edemeyen Suriyeli çocukların eğitimi sorunudur. Elde edilen bulgular, bu iki başlık dikkate alınarak ayrı ayrı tartışılacaktır.

Elde edile bulgulardan yola çıkarak Van ilindeki devlet okullarının herhangi birinde öğrenim gören Suriyeli öğrencilerin yaşadıkları sorunların en başında maddi sorunlar gelmektedir. Elde edilen verilere göre, Suriyeli ailelerin temel anlamda yaşadıkları barınma ve beslenme sorununun çocukların eğitimine yansıdığı görülmektedir. Ailelerin neredeyse tümü maddi anlamda sorunlar yaşamakta ve bu sorunlardan dolayı çocukların eğitim ihtiyaçlarını, okul araç ve gereçlerini karşılayamamaktadırlar. Yapılan başka araştırmalarda da benzer sonuçlara ulaşılmıştır. Sevim (2001), araştırmasında göç eden çocukların bir kısmının ekonomik sıkıntıların etkisiyle okula devamlarının aksadığını dile getirmiştir.

Dil sorunu ve okul kültürüne uyum sorunu okulda yaşanan önemli sorunlardan diğerleridir. Akalın'ın (2016) Suriyeli göçmen çocuklarının uyumu üzerine yaptığı çalışmasında göçten sonra dil ve uyum sorununun en önemli sorunlardan olduğu sonucuna varması araştırmamızı desteklemektedir. Suriyeli çocuklar, hiçbir ön hazırlıktan geçirilmeden 
ve dil sorunu halledilmeden sınıf ortamına alınmışlardır. Süreç içerisinde bazı okullar, uyum çalışmaları yapmış ve okuma-yazma veya dil kursu açarak öğrencileri bu eğitimlere tabi tutmuş böylelikle öğrencilerin bu sorunlarını gidermeye çalışmıştır. Ancak elde edilen verilere göre tüm okullarda bu tür çalışmalar yapılamamıştır. Bu noktada bazı öğrenciler dil ve uyum problemlerini kısmen aşarak eğitimine devam etmeye çalışırken diğer taraftan bazı öğrenciler dil ve uyum sorununu aşamadıkları için eğitim öğretim faaliyetlerinden yeterince faydalanamamışlardır.

Elde edilen verilere göre, Suriyeli öğrencilerin yabancılık, yalnızlık, dışlanma, derslerde başarısızlık gibi sorunlar yaşadıkları sonucuna ulaşılırken; okulun bu öğrencilere sosyalleşme, yeni arkadaşlar edinme, yeni bir kültürü tanıma, psikolojik sorunların çözülmesinde yardımcı olma gibi katkıları olduğu sonucuna da ulaşılmıştır. Bunun yanı sıra, okulda yaşanan bu sorunların giderilmesine yönelik öğrencilerin maddi yardımda bulunulması, Türkçe dilinin öğrenilmesi için gerekli kursların açılması, eğitim dilinin Arapça olması ve öğretmenlerin daha ilgili olması gibi istekleri doğrultusunda okul yöneticileri ve öğretmenler tarafindan çeşitli tedbirler alınmaya çalışılmış fakat bu tedbirlerin kısmen faydalı olduğu, okulun şartları ve imkânlarının yeterli olmadığı sonucuna varılmıştır.

Araştırmada elde edilen bulgulara göre, Van ilinde bulunan okul çağındaki Suriyeli çocukların okula devam etmeme nedenlerinin başında yine maddi sorunlar bulunmaktadır. Evde çalışacak birilerinin olmaması ve temel ihtiyaçların karşılanamaması çocuk işçiliği sorununu ortaya çıkarmıştır. Bir işte çalışma zorunluluğu ise çocukların okula gitmesinin önünde önemli bir sorun olarak görülmektedir. Kalacak evlerinin olmaması ve sürekli yer değiştirmeleri Suriyelilerin okula devam etmeme nedenleri arasında dikkat çeken bir diğer sorun olarak görülmektedir. Bazı aileler, kira ödeyebilecek maddi olanaklara sahip olmadıklarından kenar mahallelerde terk edilmiş tek gözlü evlerde veya şehir dışına doğru boş alanlarda çadırlar kurarak yaşamlarını sürdürmeye çalışmaktadır. Ancak daha uygun bir yer bulma ümidiyle aileler sürekli yer değiştirmek zorunda kalmaktadır. Herhangi bir yerde kalıcı olarak kalmadıkları için de çocukların okula gitmesine veya gönderilmesine sıcak bakılmadığı sonucuna ulaşılmıştır. İnsanların temel ihtiyaçlarının beslenme ve barınma olduğu düşünüldügüünde, göç eden ailelerin temel ihtiyaçlarını giderme problemi varsa eğitimin en önemli sorun olması elbette ki normal değildir. Aile halkının öncelikle bu ihtiyaçlarına önem vermesi eğitimi ikinci plana atmıştır. Fakat İçli (1999), çalışmasında göç eden ailelerin eğitim 
ve meslek düzeyleri düşük olmasına rağmen eğitime önem verdikleri, çocukları için iyi bir eğitim istedikleri sonucuna varmıştır.

Bunun yanı sıra, dil farklılığının olması nedeniyle çocukların okulda öğretmenlerini anlayamayacakları ve arkadaşlarıyla iletişime geçemeyecekleri düşüncesi, bazı ailelerin henüz vatandaşlık kimliği edinememeleri ayrıca okul hakkındaki yanlış duyumlar da okula gitmeme nedenlerine ilişkin ulaşılan sonuçlardan diğerleridir. $\mathrm{Bu}$ noktada okula devam etmeyen çocukların ve Suriyeli ailelerin maddi yardım, barınma sorunlarının giderilmesi, sadece Suriyelilerin bulunduğu okulların açılması ve buralarda Arapça bilen öğretmenlerin veya Suriyeli öğretmenlerin eğitim vermesi gibi taleplerinin olduğu sonuçlarına da ulaşılmıştır.

Sonuç olarak, Van ilinde yaşamlarını sürdürmeye çalışan Suriyeli mültecilerin eğitimi sorunundan önce barınma ve beslenme gibi temel ihtiyaçlarının giderilmesi gerekmektedir. $\mathrm{Bu}$ konuda vicdan sahibi her insanın kendi imkânları nispetinde her şeyden önce bir insan olarak sorumluluğu bulunmaktadır. $\mathrm{Bu}$ sorunlar halledildikten sonra okul çağındaki Suriyeli çocukların ileride sorun teşkil edecek bir grup olmaması adına araştırmacının aşağıda sunduğu naçizane önerilerinin de dikkate alınarak bu çocukların bir an önce eğitime dâhil edilmesi gerekmektedir.

\section{Öneriler}

Çalışmada elde edilen bulgular ve ulaşılan sonuçlardan hareket ederek aşağıdaki önerilerde bulunulabilir:

1. Van ilinde yaşayan Suriyelilerin ve okul çağındaki Suriyeli çocukların demografik verileri toplanarak sağlıklı bir tespit yapılabilir.

2. Ailelerin eğitimden önce öncelikli olan barınma ve beslenme gibi temel ihtiyaçları giderilmelidir. Bu tür çalışmalar sivil toplum kuruluşlarının katkısıyla yapılabilir.

3. Devlet okullarına kayıtların yapılabilmesi için gerekli olan vatandaşlık kimliğinin (geçici koruma belgesi) hazırlanması süreci hızlandırılabilir.

4. Okullara kaydedilen öğrencilerin sınıf ortamına alınmadan önce hazırbulunuşluk düzeyleri tespit edilebilir.

5. Dil farklılığından kaynaklı sorunların olmaması için Türkçe dil kursları veya okumayazma kursları açılarak çocuklar bu eğitimden geçirilebilir. Dil problemi ortadan kalktıktan sonra öğrenciler örgün eğitime dâhil edilebilir. 
6. Çocukların eğitim için gerekli materyaller, araç ve gereçler, okul üniforması, okula ulaşımı gibi tüm ihtiyaçları ücretsiz karşılanabilir.

7. Okul yöneticilerine, öğretmenlere ve okul personellerine Suriyelilerin zorlu yaşam koşulları, hakları ve faydalanabilecekleri hizmetler hakkında bilgi sahibi olmaları için eğitimler verilebilir.

8. Aileler okula davet edilip veya veli ziyaretleri kapsamında ailelerle sık sık görüşmeler yapılabilir.

9. Çocukların eğitimleri konusunda sivil toplum kuruluşları daha aktif rol üstlenebilir.

10. Bu konuda valilik, belediyeler, milli eğitim müdürlükleri, vakıflar ve sivil toplum kuruluşları arasında işbirliği sağlanıp projeler yürütülebilir.

\section{Çalışmamızın Söz Konusu Sorunu Çözmeye Yönelik Katkıları}

2017 yılında yüksek lisans tez çalışması kapsamında Türkiye’nin tüm illerinin ortak sorunu haline gelen Suriyelilerin eğitimi sorunu, Van ili özelinde ele alınarak incelenmiştir. Tezimizin bir bölümünün makale haline getirildiği yukarıdaki halinde de görüleceği üzere Suriyelilerin eğitimi noktasında farklı paydaşlarla görüşülüp var olan sorunlar belirlenmeye çalış1larak bu sorunların giderilmesine yönelik çözüm önerileri geliştirilmeye çalış1lmıştır.

Tez sürecinde çok sayıda Suriyeli mülteciyle görüşmeler yapılmış; ancak genel sorunlar, ortak ve benzer olduğundan belirli sayıda katılımcının görüşleri çalışmada değerlendirilmiştir. Veri toplama sürecinde Suriyelilerin çaresizliklerine ve yaşadıkları sorunlara birebir şahit olunduğundan bir yandan eğitim ile ilgili yaşadıkları sorunlar tespit etmeye çalışılırken; diğer taraftan da tespit edilen ailelerin temel ihtiyaçları geniş bir gönüllü kitlesinin olağanüstü gayreti ve sivil toplum kurullarının desteğiyle giderilmeye çalışılmıştır. Bu noktada çalışmamızın adeta bir sosyal proje niteliğinde olduğunu söylemek mümkün olacaktır.

Tahmin edilenin ötesinde önemli sonuçlar ve çözüm önerileri elde edilen çalışmamızın kâğıt üzerinde kalmaması ve var olan bu sorunların ortadan kalkmasına bir nebze olsun katkı sunabilmesi adına çalışmamızın bir nüshası, 2017 yılı Ekim ayında Van Valiliği’ne sunulmuştur. Dönemin vali yardımcısı tarafından incelenen çalışmamız, Suriyelilerin ildeki genel durumu ve eğitim sorunları açısından önemli veriler içerdiği için kendilerinden takdir görmüş ve emirleri doğrultusunda konunun bu çalışma ekseninde yeniden ele alınması için geniş bir paydaş kitlesinin katılımıyla bir toplantı düzenlenmiştir. vali yardımcısının 
Van YYÜ Eğitim Fakültesi Dergisi (YYU Journal of Education Faculty), 2022:Şubat Özel Sayı 28-55,http://efdergi.yyu.edu.tr,

liderliğinde, il göç idaresi müdürlüğü yöneticileri, il milli eğitim müdür vekili, yardımcıları ve şube müdürleri, ilçe milli eğitim müdürleri, il emniyet müdürlügü temsilcileri, ilçe nüfus müdürlüğü temsilcileri, ilçe sosyal yardımlaşma vakfı temsilcileri ve ilçe halk eğitim merkezi temsilcilerinin katılımıyla gerçekleşen toplantıda çalışmamızın verileri ve elde edilen çözüm önerileri kendilerine sunulmuştur. Sunumumuzun ardından elde edilen veriler ve çözüm önerileri ışığında \% 8 olan eğitim çağındaki Suriyelilerin okula devam oranının artırılmasına yönelik yapılabilecekler, paydaşlar tarafından görüşülüp tartışılmıştır. Sirkülasyondan dolayı Suriyelilerin okula devam oranının \% 100 yapılmasının mümkün olamayacağı; ancak \% 8 gibi çok az olan bu oranın öneriler 1şı̆̆ında yapılabilecek çalışmalarla artırılabileceği sonucuna ulaşılmıştır. Devam eden aylarda belirli aralıklarla il milli eğitim müdürlüğü, il göç idaresi müdürlüğü, il nüfus müdürlüğü ve il emniyet müdürlüğü temsilcilerinin katılımlarıyla toplantılar düzenlenerek yapılmakta olan ve yapılacak olan çalışmalar takip edilerek bir sonuca ulaşılmaya çalışılmıştır.

Yapılan bu toplantılar ve çalışmalar sonucunda yaklaşık bir yıllık süre zarfında eğitim çağındaki Suriyeli öğrencilerin okula devamı oranında gözle görülür bir değişiklik olmuştur. İller arası Suriyelilerin göç sirkülasyonunun çok fazla olduğunun bilinmesinin yanı sıra, Göç İdaresi Genel Müdürlüğü’nün son 3 yıldaki verilerine göre Van ilindeki Suriyeli nüfusu, 2000 - 3000 arasında değişiklik göstermektedir. Genel verilere göre, Türkiye’deki Suriyeli nüfusun 1/3’ü, 5-18 yaş aralığında olduğundan Van ilinde okul çağındaki Suriyeli öğrencilerin sayısının 700 ile 1000 arasında olduğu söylenebilmektedir. Aşağıda eğitim-öğretim yıllarına göre Van ilindeki devlet okullarına kayıtlı Suriyeli öğrenci sayıları verilmiştir:

Tablo 10. Van İlindeki Okullarda Kayıtlı Suriyeli Öğrenci Sayısı (2016-2017)

\begin{tabular}{lccccc}
\hline İlçe & Ana sınıfi & İlkokul & Ortaokul & Lise & Toplam \\
\hline Edremit & 3 & 9 & 1 & 1 & $\mathbf{1 4}$ \\
Erciş & 2 & 6 & 1 & 1 & $\mathbf{1 0}$ \\
Gürpınar & - & - & 1 & - & $\mathbf{1}$ \\
İpekyolu & 3 & 11 & 3 & 1 & $\mathbf{1 8}$ \\
Özalp & - & 1 & - & - & $\mathbf{1}$ \\
Tuşba & 5 & 20 & 8 & 3 & $\mathbf{3 6}$ \\
\hline Genel Toplam & $\mathbf{1 3}$ & $\mathbf{4 7}$ & $\mathbf{1 4}$ & $\mathbf{6}$ & $\mathbf{8 0}$ \\
\hline
\end{tabular}


Van YYÜ Eğitim Fakültesi Dergisi (YYU Journal of Education Faculty), 2022:Şubat Özel Sayı 28-55,http://efdergi.yyu.edu.tr,

Kaynak: Van İl MEM (Mayıs, 2017)

Tablo 10’da görüldüğü üzere Mayıs 2017'de alınan verilere göre 2016-2017 EğitimÖğretim yılında Van ilinde bulunan eğitim çağındaki yaklaşık 1000 öğrencinin yalnızca 80 tanesi, başka bir ifadeyle \% 8'i okula gitmektedir.

Tablo 11. Van İlindeki Okullarda Kayıtlı Suriyeli Öğrenci Sayısı (2017-2018)

\begin{tabular}{lccccc}
\hline İlçe & Ana sinıfi & İlkokul & Ortaokul & Lise & Toplam \\
\hline Edremit & 2 & 6 & 1 & 2 & $\mathbf{1 1}$ \\
Erciş & 1 & 17 & 1 & 1 & $\mathbf{2 0}$ \\
Gürpınar & - & - & 1 & - & $\mathbf{1}$ \\
İpekyolu & 2 & 38 & 13 & 1 & $\mathbf{5 4}$ \\
Özalp - Muradiye & 3 & - & - & - & $\mathbf{3}$ \\
Tuşba & 7 & 30 & 8 & 5 & $\mathbf{5 0}$ \\
\hline Genel Toplam & $\mathbf{1 2}$ & $\mathbf{9 4}$ & $\mathbf{2 4}$ & $\mathbf{9}$ & $\mathbf{1 3 9}$ \\
\hline
\end{tabular}

Kaynak: Van İl MEM (Ocak, 2018)

Tablo 11’de görüldüğü üzere 2018 yılı Ocak ayında alınan verilere göre, 2017-2018 Eğitim-Öğretim yılında Van ilinde bulunan eğitim çağındaki yaklaşık 1000 öğrencinin 139 tanesi, başka bir deyişle \% 14'ü okula devam etmektedir.

Tablo 12. Van İlindeki Okullarda Kayıtlı Suriyeli Öğrenci Sayısı (2018-2019)

\begin{tabular}{lccccc}
\hline İlçe & Ana sinıfi & İlkokul & Ortaokul & Lise & Toplam \\
\hline Edremit & 2 & 6 & 3 & 2 & $\mathbf{1 3}$ \\
Erciş & 8 & 25 & 3 & 3 & $\mathbf{3 9}$ \\
Gürpınar & - & - & 1 & - & $\mathbf{1}$ \\
İpekyolu & 5 & 45 & 25 & 5 & $\mathbf{8 0}$ \\
Özalp - Muradiye & - & 3 & - & - & $\mathbf{3}$ \\
Tuşba & 7 & 40 & 15 & 14 & $\mathbf{7 6}$ \\
\hline Genel Toplam & $\mathbf{2 2}$ & $\mathbf{1 1 9}$ & $\mathbf{4 7}$ & $\mathbf{2 4}$ & $\mathbf{2 1 2}$ \\
\hline
\end{tabular}

Kaynak: Van İl MEM (Şubat, 2019)

Göç İdaresi Genel Müdürlüğü'nün 21.03.2019 tarihinde yayınlamış olduğu Geçici Koruma Kapsamındaki Suriyelilerin İllere Göre Dağılımı tablosuna göre Van ilinde 2.136 Suriyeli bulunmaktadır (GİGM, 2019). Genel veriler göz önüne alındığında, 2018-2019 Eğitim-Öğretim yılında Van ilinde eğitim çağında olan yaklaşık 700-800 Suriyeli olduğu söylenebilmektedir. Tablo 12’de görüldügü üzere, 2019 yılında Van İl Milli Eğitim Müdürlüğü’nden alınan verilere göre, 2018-2019 Eğitim-Öğretim yılında Van ilinde bulunan eğitim çağındaki Suriyeli öğrencilerin 212 tanesi, başka bir ifadeyle yaklaşı \% 30’u okula devam etmektedir. 
Van YYÜ Eğitim Fakültesi Dergisi (YYU Journal of Education Faculty), 2022:Şubat Özel Sayı 28-55,http://efdergi.yyu.edu.tr,

Çalışmamızın yapıldığı Ocak-Mayıs 2017 tarihleri arasında Suriyelilerin okula devam oranı, \% 8 iken sonrasında elde edilen veriler ve çözüm önerileri ışığında bir sonraki eğitimöğretim yılında bu oranın \%14'e; bir sonraki eğitim-öğretim yılında ise bu oranın \% 30'a ulaştığı görülmüştür.

\section{Makalenin Bilimdeki Konumu}

Eğitim Yönetimi, Teftişi, Planlaması ve Ekonomisi ABD

\section{Makalenin Bilimdeki Özgünlüğü}

Türkiye’de bulunan Suriyeli mültecilerin genel durumu önemli bir problem olarak ülkemizi yakından ilgilendirmektedir. Özellikle eğitimleri noktasında eldeki veriler, ülkelerinde eğitimlerini yarıda bırakarak Türkiye'ye gelen ve eğitimine devam etmesi gereken binlerce Suriyeli çocuğun olduğunu göstermektedir. Bu durum, Türkiye’nin Suriyeli çocuklara yönelik uzun vadeli eğitim politikaları geliştirmesini zorunlu kılmaktadır. Türkiye’de yaşamlarını sürdüren okul çağındaki Suriyeli çocukların eğitim sürecinde yaşadıkları sorunların belirlendiği ve bu sorunlara getirilen çözüm önerilerinin değerlendirildiği bu çalışmanın, hali hazırda Türkiye'nin gündeminde olan bu önemli konuya ve bu bağlamda yapılacak olan farklı çalışmalara katkı sağlayacağı düşünülmektedir.

\section{Kaynaklar}

AFAD (Afet ve Acil Durum Yönetimi Başkanlığı) (2016). Suriye raporlarl. T.C. Başbakanlık Afet ve Acil Durum Yönetimi Başkanlı̆̆ı. https://www.afad.gov.tr/tr/2376/Suriye$\underline{\text { Raporlari }}$

Akalın, A. T. (2016). Türkiye’ye gelen Suriyeli göçmen çocukların eğitim sorunları. (Yüksek Lisans Tezi), İstanbul Aydın Üniversitesi Sosyal Bilimler Enstitüsü, İstanbul. 
Van YYÜ Eğitim Fakültesi Dergisi (YYU Journal of Education Faculty), 2022:Şubat Özel Sayı 28-55,http://efdergi.yyu.edu.tr,

Duban, N. ve Küçükyılmaz, E. A. (2008). Sınıf öğretmeni adaylarının alternatif ölçme değerlendirme yöntem ve tekniklerinin uygulama okullarında kullanımına ilişkin görüşleri. İlköğretim Online. 7(3). 774.

GİGM (Göç İdaresi Genel Müdürlüğü) (2017). Göç istatistikleri. http://www.goc.gov.tr/icerik3/gecici-koruma adresinden 07.07.2017 tarihinde alınmıştır. GİGM (Göç İdaresi Genel Müdürlüğ̈) (2019). Göç istatistikleri. http://www.goc.gov.tr/icerik6/gecici-koruma_363_378_4713_icerik adresinden 21.03.2019 tarihinde alınmıştır.

İçli, G. (1999). Denizli iline göç eden ailelerin eğitime bakış açıları. Pamukkale Üniversitesi Ĕ̆itim Fakültesi Dergisi, 5: 70-74.

MEB (Milli Eğitim Bakanlığı) (2014). Yabancılara yönelik eğitim-öğretim hizmetleri. http://mevzuat.meb.gov.tr adresinden 18.07.2017 tarihinde alınmıştır.

Neuman, W. L. (2014). Toplumsal araştırma yöntemleri nitel ve nicel yaklaşımlar. (Çev. S. Özge). Yayınodası.

Sevim, Y. (2001). Terör nedeniyle Elazığ'a göç eden ailelerin çocuklarının eğitim durumu. Firat Üniversitesi Sosyal Bilimler Dergisi, 11(2): 260-267.

UNHCR (The UN Refugee Agency) (2015) Türkiye’deki Suriyeli mülteciler: S1k sorulan sorular. http://www.unhcr.org/adresinden 23.12.2016 tarihinde alınmıştır.

UNICEF (Birleşmiş Milletler Çocuk Fonu) (2015). Türkiye'deki Suriyeli çocuklar. Aralık raporu. http://www.unicef.org.tr/

UNİCEF (Birleşmiş Milletler Çocuk Fonu) (2016). Türkiye'deki Suriyeli çocuklar. Şubat raporu http://www.unicef.org.tr/

Yıldırım, A. ve Şimşek, H. (2008). Sosyal bilimlerde nitel araştırma yöntemleri (6. Baskı). Seçkin Yayıncılı.

Yılmaz, İ. (2017). Türkiye'de kaç Suriyeli öğrenci var?. Bağımsız İnternet Gazetesi. http://www.m.t24.com.tr adresinden 19.07.2017 tarihinde alınmıştır.

\section{Summary}




\section{Statement of Problem}

Due to the internal conflicts and turmoil in Syria, 252 people entered Turkey from Syria for the first time in 2011 and since this date, the number of Syrians who took refuge in Turkey has gradually increased (AFAD, 2016). Millions of people have been affected by these conflicts. In this process, thousands of people were injured and many people lost their lives. By 2015, more than half of the Syrian population had to leave their lands and migrate to different countries. A significant portion of the Syrians who migrated took refuge in neighboring countries such as Turkey, Lebanon, Iraq and Egypt (UNCHR, 2015). Undoubtedly, Turkey has had a great importance for Syrians due to its location in this migration process. Turkey hosts a significant portion of the Syrians who had to migrate from their countries due to the civil war and conflicts that started in Syria in 2011.

According to the age and gender data of the GİGM (2017) Syrians in Turkey, 1.410 .080 of the Syrians in Turkey are children. In other words, nearly half of the Syrians in Turkey are between the ages of $0-18$. The number of children of school age is $1,030,388$. In other words, 33 percent, or one-third, of the Syrian refugees in Turkey is of education age. This data shows that there are hundreds of thousands of Syrian children who have left their education in their country and need to continue their education. This situation obliges Turkey to develop longterm education policies for Syrian children.

\section{Purpose of the Study}

The aim of this study is to disclose the education problems of the Syrian refugees who are at educational age and lead a life in Van, and also try to find suitable solutions for this problem.

\section{Method}

This study is a descriptive survey model which is a case study. The study group is consisted of 46 people; 13 Syrian refugee children who have migrated to Turkey and have lived in Van (7 of them attend to school while 6 of them do not), 6 Syrian householders, 8 teachers and 5 school managers from the schools in which Syrian students have education in Van, 2 provincial administrators of national education (one assistant of provincial administrator of national education, one departmental manager of provincial directorate for national education), 
Van YYÜ Eğitim Fakültesi Dergisi (YYU Journal of Education Faculty), 2022:Şubat Özel Sayı 28-55,http://efdergi.yyu.edu.tr,

7 education inspectors who work in Van, 1 administrator of social assistance and solidarity foundation and 4 civil society organizations (2 unions and 2 charities) which serve actively. The data is obtained with the interview technique which has been made by structured form. The study data is analyzed with content analysis method.

\section{Findings, Discussions and Conclusions}

According to the data obtained, although there are nearly 1000 school-age Syrians in Van, only 80 of them, 8\%, benefit from education and training activities in public schools. 92\% of these children do not continue their education. According to the findings, it was concluded that although these children wanted to go to school very much, they could not go to school due to various reasons such as financial impossibility, constant relocation, and language problems.

The problem of education of Syrian children of educational age in the province of Van should be handled and evaluated fewer than two different headings. First, the problem of education of Syrian children currently studying in any of the public schools; the second is the education problem of Syrian children who cannot continue their education for various reasons.

Based on the findings, financial problems come at the top of the problems experienced by Syrian students studying in any of the state schools in Van. According to the data obtained, it is seen that the basic housing and nutrition problems experienced by Syrian families are reflected in the education of their children. Almost all of the families have financial problems and because of these problems, they cannot meet the educational needs of the children, school tools and equipment.

According to the data obtained, it was concluded that Syrian students experienced problems such as alienation, loneliness, exclusion, failure in lessons and language problems; It was also concluded that the school contributed to these students such as socializing, making new friends, getting to know a new culture, and helping them solve psychological problems.

According to the findings of the study, financial problems are the main reason for school-age Syrian children in Van not to attend school. Obligation to work at a job is seen as an important problem for children to go to school. The lack of a house to stay and their constant relocation are seen as another striking problem among the reasons why Syrians do not attend school. Families have to constantly relocate in the hope of finding a more suitable place. It has been concluded that children are not welcomed to go to school or be sent because they do not 
stay in any place permanently. Giving importance to these needs of the family members put education on the second plan.

In addition, the thought that children will not be able to understand their teachers and communicate with their friends at school due to language differences, and the fact that some families have not yet acquired citizenship identity are some of the reasons for not going to school. At this point, it has been concluded that the children who do not attend school and Syrian families have requests for financial aid, to solve their housing problems, to open schools where only Syrians are present, and to provide education by Arabic-speaking teachers or Syrian teachers.

\section{Recommendations}

Based on the findings and conclusions reached in the study, the following recommendations can be made:

1. The basic needs of families, such as shelter and nutrition, should be met before education. Such studies can be carried out with the contribution of non-governmental organizations.

2. The process of preparing the citizenship identity (temporary protection document), which is required for enrollment in public schools, can be accelerated.

3. Readiness levels of students enrolled in schools can be determined before they are admitted to the classroom environment.

4. In order to avoid problems arising from language differences, Turkish language courses or literacy courses can be opened and children can undergo this training. After the language problem disappears, students can be included in formal education.

5. All the needs of children such as materials, tools and equipment, school uniform, transportation to school can be met free of charge.

6. Families can be invited to school or frequently interviewed within the scope of parent visits.

Keywords: Migration, Syria, Education problems, Migration and education, Syrian refugees. 